\section{ACRL}

\section{Cuidelines}

\title{
The redefining scholarship project: A draft report
}

\author{
By the ACRL Institutional Priorities and Faculty Rewards \\ Task Force
}

\section{Please review this report and send your comments to the Task Force}

$\mathbf{A}$ t the July 1996 ALA Annual Conference the ACRL Board of Directors appointed a task force to write a formal statement defining and describing the kind of scholarship performed by academic librarians, using as a framework the taxonomy developed by Eugene Rice and elaborated by Ernest Boyer in his 1990 book Scholarship Reconsidered: Priorities of the Professoriate.' The task force's statement, upon approval by the ACRL Board, is intended to become part of a larger movement established by Syracuse University's Center for Instructional Development, entitled the Institutional Priorities and Faculty Rewards project. The project, which is being funded by the Lilly Endowment with support from the Fund for the Improvement of Postsecondary Education, is providing assistance to academic associations for the development and dissemination of definitions of scholarship for their disciplines. The definitions are intended to extend the range of activities recognized as scholarly for the purposes of tenure, promotion, merit, or reward system guidelines. The following is the report of the ACRL task force.

\section{Background information}

The movement to gain faculty status for American academic librarians that began in the 19 th century celebrated a major milestone when ACRL adopted the "Standards for Faculty Status for College and University Librarians" in 1971. The Standards were intended to de- fine and describe the rights and responsibilities which ACRL believed should be exercised by librarians at American colleges and universities. However, in spite of the fact that some form of faculty status has been instituted for librarians at many postsecondary institutions and endorsed by organizations such as the American Association of University Professors, the debate over the appropriateness of faculty status within the academic library profession has not abated. One of the most persistent objections to faculty status for librarians has been that the research that is expected of most faculty should not be required of librarians, for it is not a normal part of librarians' daily responsibilities. Many have argued that academic librarians, as practitioners of an applied field, are not engaged in the kind of scholarship that faculty must perform in order to earn promotion and tenure. Efforts to demonstrate that much of what librarians do is scholarly or "like what other faculty do" were criticized as attempts to force square pegs into round holes. It was further contended that if librarians were made to carry out research agendas to meet promotion and tenure criteria, such efforts would divert the librarians' energies from providing quality library services. But with a new and growing awareness in academia that the traditional conception of scholarship may have been too narrow, the issue of what, if anything, constitutes scholarship done by academic librarians may be considered in a new light.

In Making a Place for the New American Scholar, Eugene Rice describes Boyer's Scholarship Reconsidered as having "called on faculty to move beyond the tired old 'teaching vs. research' debate. .. . What moves to the fore- 
ground is the scholarly work of faculty, whether they are engaged in the advancing of knowledge in a field, integrating knowledge through the structuring of a curriculum, transforming knowledge through the challenging intellectual work involved in teaching and facilitating learning, or applying knowledge to a compelling problem in the community." ${ }^{2}$ These four types of scholarship-which we shall call inquiry, integration, teaching, and application-provide a framework for considering how the activities of academic librarians may fit into the broader, more complete understanding of what constitutes academic work. Such a re-examination is very timely in light of the similar efforts being carried out in the Institutional Priorities and Faculty Rewards project by dozens of other professional associations on behalf of their academic disciplines. The next section of this report considers the primary activities of academic librarians as they relate to the different categories of scholarship and other faculty responsibilities.

\section{The roles of academic librarians}

The roles of faculty members are usually consiclered to fall into three categories: teaching, scholarship, and service to the institution and profession. Efforts to place the activities of librarians into these categories have not been problematic as far as service was concerned, since academic librarians are committed to the strengthening of their profession through formal associations and other activities, while service on campus benefits the librarians as well as the institution by virtue of the librarians' participation in the planning and decision-making process. Where difficulties have been encountered are in the categories of scholarship (because of the objections described above) and teaching, where attempts to equate responsibilities such as reference, cataloging, and collection development with classroom instruction have been met with skepticism. However, by using the taxonomy of Rice and Boyer it becomes clear that while the teaching of librarians is different from that done by most other faculty, many of the primary faculty roles of librarians - roles which they perform on a daily basis-are in fact scholarly in nature.

\section{Teacbing}

The teaching that is most characteristic of academic librarianship involves instructing people in becoming independent scholars who can find, assess, and use information resources ef- fectively. ACRL's "Model Statement of Objectives for Academic Bibliographic Instruction" recommends the following general objectives for a bibliographic instruction program:

- the student will understand how information is defined by experts, and recognize how that knowledge can help determine the direction of his/her search for specific information;

- the student will understand the importance of the organizational content, bibliographic structure, function, and use of information sources;

- the student will be able to identify useful information from information sources or information systems;

- the student will be able to understand the way collections of information sources are physically organized and accessed. ${ }^{3}$

Librarians teach users to plan and carry out search strategies appropriate to given needs, and to evaluate the extent to which various texts and databases may be considered authoritative and up-to-date

Librarians teach these skills in a variety of ways; most commonly, instruction is delivered as librarians serve individuals at the reference desk or meet with classes as guest lecturers. At many institutions librarians conduct for-credit bibliographic instruction classes that last the entire academic term and teach library research skills in depth. Other effective means of teaching library skills include term paper clinics, workshops on electronic information retrieval skills, and extended reference consultation with students, faculty, and other library users. Just

\section{Comments sought}

The ACRL Institutional Priorities and Faculty Rewards Task Force is seeking comments and suggestions regarding this draft of its report to the ACRL Board of Directors. A hearing is scheduled from 2:00 to $4: 00$ p.m. On Sunday, June 29, at the ALA Annual Conference in San Francisco. Comments may also be sent prior to the hearing to Task Force chair W. Bede Mitchell, Associate University Librarian, Belk Library, Appalachian State University, Boone, NC 28608; MITCHELLWB@APPSTATE.EDU. 
as with other kinds of library skill teaching, research consultation involves a considered judgment about a patron's educational background and capabilities, and an understanding of the relative intellectual merits of the library's resources.

\section{Scholarship}

As previously noted, a major proportion of the work done by librarians qualifies as scholarship.

A. Inquiry. Librarians engage in the scholarship of inquiry when they seek to answer such questions as:

- What are the most efficient and effective means of organizing information and retrieving it when it is sought?

- How can we determine and meet a user's true information need when research has shown that a sizable proportion of all users are not able to articulate their needs clearly and completely?

- How do we ensure that library collections and services are contributing substantially to the educational goals of our institutions?

- What information resources should we be providing to our unique set of patrons?

- Which media are most effective for the specific kinds of information preservation and use needs that we have?

- How can we construct Wels pages and other tools that help students and faculty navigate "cyberspace" effectively?

There is a vast set of more specific research questions which attempt to address smaller, more manageable aspects of the above questions, but the foregoing is evidence that there is a formidable agenda for extending the knowledge base of librarianship.

B. Integration. Academic librarianship has drawn upon a wide range of other disciplines for knowledge that informs and transforms library work. The considerable extent to which academic librarians integrate knowledge from other fields makes for a highly interdisciplinary profession.

Examples of the integration of knowledge from other fields into the scholarship and practice of librarianship include:

- drawing upon learning theory in order to design effective instruction;

- employing communication theory to improve the reference interview and establish sound communication throughout the library organization;
- applying the findings of ergonomic studies to the design of space for library users and personnel that will be conducive to human work and comfort;

- protecting for future generations of scholars the library's collections from environmental and usage-imposed dangers by means of preservation techniques;

- assisting users by interpreting and analyzing the components of their information needs and helping construct efficient and comprehensive research strategies, which often requires a thorough knowledge of the literature of several disciplines;

- integrating administrative and management techniques into the operation of a complex service organization;

- advising fellow faculty about the constraints of copyright and the allowances for educational fair use of copyrighted materials in print and multimedia formats.

C. Teaching. The scholarship of teaching involves developing, testing, and improving pedagogical techniques for meeting the instruction objectives described in B.1. above, and communicating to peers the results of testing the techniques

D. Application. As a service profession, academic librarianship applies the theory and knowledge gained through inquiry, integration, and pedagogical experimentation to meeting the research and learning needs of the academic community. By employing the results of the scholarship exemplified in the foregoing sections, academic librarians attempt to improve and refine their processes and programs.

\section{Service}

Academic librarians are heavily involved in service to their academic institution, profession, and to the general public in the form of outreach. Service activities benefit both the librarians - increasing their ability to design and manage responsive and effective library services-and the groups to which they contribute. By participating in institutional planning and decision-making, librarians are better able to ensure that library goals, services, and collections reflect and support the institutional mission and priorities. The scope and character of library resources are essential components in delivering quality education, and institutional service enables librarians to manage those resources effectively as a result of a thorough understanding of the institution's curricu- 


\title{
ON AUDIOCASSETTE TAPES
}

\section{ASSOCIATION OF COLLEGE \& RESEARCH LIBRARIES 8th National Conference}

\author{
April 11 - 14, 1997 Nashville, Tennessee
}

The Association of College and Research Librarles was professionally recorded by IntoMedla. Audiotape copies of the presentations are available via mail, phone or lax orders. Please allow 3 to 4 weeks for delivery. Each tape is an unedited transcript of the actual program, with all the information and energy of the live presentation. InfoMedia is not responsible for any speaker's or registrant's statements, materials, acts or omissions. All audiotapes are guaranteed for one year from the date of purchase. All Sales Are Final.

PROGRAM NUMBER MQ146 (Check The Box By The Session(s) You Wish To Purchase)

MQ146-1

$\$ 8.00$

MQ146-2 $\$ 8.00$

$M Q 146-3$ $\$ 8.00$

MQ146-6 $\$ 8.00$

MQ146-7 $\$ 8.00$

$M Q 146-8$ $\$ 8.00$
Greetings, P. Bredesen; Welcome, W. Miller; Introduction, J. Williams, III; Race Matters, C. West $\$ 8.00$

Ethnic Cyber-Communities, K. Lam; Delivery of Information via the World Wide Web: A Look at Copyright and Intellectual Property Issues, V. Gregory

Books Not for College Libraries: A Singular Proposal, E. Farber; Social Equity and Empowerment in the Age of Technology, J. Diaz

Choosing Our Leaders: Team Leader Selection and Review Processes at the University of Arizona Library, C. Russell, N. Simons; Small-College Library Directors:Getting in the Door and Surviving on the Job, J. O'Keeffe

Beyond Bibliography: Advanced Information Technologies, the Humanities, \& the Library, J. Kibbee; The Library \& Academic Computing Center: Cultural Perspectives and Recommendations for Improved Interaction, R. Favini

The Gods Never Had It So Good: Partnerships, Standards, and Navigational Tools for Access to Images, D. Austin, J. Hodson; Building Partnerships: A World Wide Web-based Information Management/Preprint Tool for Research Scientists, Government Researchers and Industrial Partners in the Phase Separation Project, L. Bartolo

Setting the Agenda for Special Collections in the 21st Century, A. Schreyer, T. Hickerson

MQ146-10 $\$ 8.00$

MQ146-11 $\$ 8.00$

MQ146-12 $\$ 8.00$

MQ146-13 $\$ 8.00$

MQ146-14 $\$ 8.00$

MQ146-15 $\$ 8.00$

MQ146-16 $\$ 8.00$
Policies and Issues Related to African American Archives, Electronic Information, and Diversity: An Urgent Agenda, E. J. Josey, A. Shockley, I. Zulu, V. Evans

\section{Redefining Scholarship} W. Mitchell, B. Moran, B. Adam

The State of Performance Measures in Academic Libraries, M. Kyrillidou, A. Lakos, C. McClure, W. Crowe

Library Advocacy: Effective Strategies for Building Support in the Academic Environment, M. Crist, S. Reed, P. Schuman, S. Stroyan, A. Symons

Choosing an Expanded Future: New Leadership Roles for Academic Librarians, E. Cline, K. Pflueger, A. Hirshon, E. Waite

Capitalizing on the Library Investment, M. Keller; Moderator: K. Nagy; K. Dowlin, P. Gherman

Assessing Library Learning to Improve Teaching and Outcomes, P. Dempsey, M. Adams, B. Gratch, K. Fenno-Smith, D. Gilchrist, B. Osif, S. Henthorn, M. Royse 
口MQ146-17 UWired Partnerships in Upper-

$\$ 8.00$

Division Courses: The Diverse Roles of Librarians, H. Williams, A. Zald,

\section{A. Bartelstein, B. Fraser}

पMQ146-18

$\$ 8.00$

MQ146-19

$\$ 8.00$

MQ146-20

$\$ 8.00$

口м0146-21

$\$ 8.00$

MQ146-22

$\$ 8.00$

MQ146-24

$\$ 8.00$

$\square \mathrm{MQ146-25}$

$\$ 8.00$

MQ146-26

$\$ 8.00$

MQ146-27

$\$ 8.00$

口MQ146-28

$\$ 8.00$

The Role of Recruitment in Achieving Goals Related to Diversity, M. Winston; The Campus

Environment for African-American and White Students: Impact on Academic Library Experience ACRL Blackwell's Student Paper Award Winner, E. Whitmire

Cutting Out the Middle: Patron-

Initiated Interlibrary Loans, B. Preece

T. Kilpatrick; Waiting for the

Electrician or Someone Like Him:

Client-Centered Technical Services, M. Bolin

Maps \& Legends: Plotting a Course for Geographic Information Systems, P. Herold; Government Information in an Electronic Age, J. Andrews

Fund-Raising Activities at Colleges and Universities in the United States, T. Latour; Are You Ripe for a Corporate Takeover? J. Gray

MQ146-33 $\$ 8.00$

MQ146-34

$\$ 8.00$

MQ146-32

$\$ 8.00$

$\$ 8.00$

MQ146-31

$\$ 8.00$

(a)

Libraries and the Post-Job Organization, L. Goetsch; The Productivity Paradox: Implications for Libraries, G. Geer, C. Hare

MQ146-36

$\$ 8.00$

Collaborating with Faculty in Preparing Students for the Asynchronous Classroom, K. Harvey, N. Dewald

MQ146-37 $\$ 8.00$

Seeking the Conceptual Foundations of Reference: Or, It's Hard to "Shake" What You Cannot Find, B. Baker, N. Pelster, W. McHugh, K. Jacobsen, I. Weiner

MQ146-38 $\$ 8.00$

Building an Ethnic and Gender

Studies Services Unit: One Library's Experience, J. Boissè, S. Curtis, P. Dawson, A. Griego, C. Gibbens, N. Llamas

Planning Strategies for Design of Learning Facilities, S. Dugdale, J. Burris, R. Braude, F. Lynch

Mission Impossible: Three Perspectives on the Future of the Academic Library, D. Leather, D. Neikirk, J. Neal
MQ146-39

$\$ 8.00$

Ma146-40 $\$ 8.00$

MQ146-41 $\$ 8.00$
Reinventing Libraries 2000: A New

Paradigm for Academia... The LSU

Experience, J. Kleiner

Changing Our Focus: A User-Driven Survey for Strategic Planning,

G. Lowell, D. Talbot

Electronics and the Future of the University, E. Noam; P. Kobulnicky: R. Martin, R. Meyer, E. Waite

Library Instruction for Off-Campus Students: Four Views of Services and Support, J. Fritts, R. Wood,

A. Casey, J. Caspers, J. Feldman,

S. Whyte

Partners in the Creation of Knowledge, B. Beaton

Virtually Here: The Future of Performance Evaluations and Process Improvement in Academic Libraries, B. Allen, R. Mitchell, E. Gerryts, M. Hammes

What's Happening at the Leading Edge: Libraries as Information Technology Centers, S. Lasoff, S. Johnson, H. Holzman, B. Fischler, C. Ferguson, C. Hurt, M. Boone

Librarians: 2001 and Beyond

S. Bentley, K. Butter, M. Larsgaard,

C. LaGuardia

Digital/Electronic Libraries in the U.S. and the U.K.: New Models for Collaboration to Promote Scholarly Communication, O. Ivins, P. Gherman W. Wakeling

Electronic Services in Academic Libraries: Using the Survey Data Effectively, R. Naylor, R. Madaus, T. Kirk, D. Leather
Restructuring Our Universities: Focusing On Student Learning, A. Guskin; S. Searing; B. Wilson, K. Frazier, S. Perry

Collaborating for Information Literacy in Graduate Education via the World Wide Web, K. Holmes

Common Ground or Quick Sand: Collaborative Instructional Improve ment, C. Middleton, T. Barr, 
MQ146-42

$\$ 8.00$

MQ146-43

$\$ 8.00$

MQ146-44

$\$ 8.00$

MQ146-45

$\$ 8.00$

MQ146-46

$\$ 8,00$

$M 0146-47$

$\$ 8.00$

MQ146-48

$\$ 8.00$

MQ146-49

$\$ 8.00$

MQ146-50

$\$ 8.00$

MQ146-51

$\$ 8.00$

$M Q 146-52$

$\$ 8.00$
Libraries and Vendors/Libraries as

Vendors: How New Methods of

Publication Create New Partnerships

and New Competitors, L. Dobb,

I. Rockman, E. Davis

Lilly Climate for Diversity Project,

Luther College, N. Hervey, W. Musser,

M. Klammer, L. Wee, C. Moorcroft

The Academic Librarian as Transformation Leader, G. Smith, M. Robinson,

B. Higginbotham, N. Nuzzo, M. Long

Serving Patrons with Disabilities:

Accessible Web Design, Adaptive

Technology, and Collaboration for

Libraries, B. Fraser, L. Wilson,

S. Bergstahler, K. Lenn, S. Beasley

The Librarian's Role in Creating

Electronic Collections, P. Willett,

S. Peters, C. Spornick, B. Day

Partnerships and Competition,

K. Nevins; M. Crist; J. Secor, L. Dowler

Project Renaissance: A Model for

Teaching and Learning at the

University of Albany, T. Jacobson,

C. Anderson, L. Brannon

Information Literacy in the Electronic Environment: The Roles of Librarians/Faculty/Students as

Teachers and Facilitators, A. Smith,

B. Rienhart, D. Richardson, T. Sagan,

G. Thompson

The Virtual Librarian: Using Desktop

Videoconferencing to Provide Interactive Reference Assistance,

K. Folger; Televideo Reference: The

UC Irvine Experience, S. Lessick,

S. Clancy, K. Kajaer, A. Love, B. Lucas

Developing a Digital Library: Scale

Requires Partnership, J. McGinty;

EdLibWeb: A Study in Cooperative

Web Site Development, J. Carr

Journals Under Attack: Faculty and

Researchers' Creative Solutions to

Access Problems (or, Theft is The

Answer: What Was the Question?)

J. Johnson, B. Rozum; Electronic

Collaboration: Key to Enhancing

Traditional Collections, C. Shabb,

J. Rieke
MQ146-53

$\$ 8.00$

MQ146-54

$\$ 8.00$

MQ146-55

$\$ 8.00$

MQ146-56

$\$ 8.00$

MQ146-57

$\$ 8.00$

MQ146-58

$\$ 8.00$

MQ146-59

$\$ 8.00$

MQ146-60

$\$ 8.00$

MQ146-61

$\$ 8.00$
Thinking Boldly! College and University Library Mission Statements as Roadsigns to the Future,

$S$. Bangert; Challenges to the Professional Control of Knowledge

Work in Academic Libraries: A

Proposed Agenda for Organizational

Research and Action, M. Day

Can We Still Do Business as Usual?:

Adult Students \& the New Paradigm

of Library Service, D. Fidishun;

Undergraduate Students and the

Digital Library: Information-Seeking

Behavior in a Heterogenous

Environment, P. Seiden,

K. Szymborski

Help-Seeking Behavior in the

Research Process of College

Students, E. Bailey, Jr.; Who?

Whom? Or, Who's Teaching What to

Whom and What Information

Services Will They Need,

M. de Jesus Ayala Schueneman

A New Model of Librarian Education for the Networked Environment,

B. Rapple, Philosophical Shift: Teach the Faculty to Teach Information Literacy, R. Smith

What Do Distance Education

Students Really Need to Learn?

E. Kirk, E. Mayotte

New York to Nashville: The Harlem

Renaissance Connection, G. Bell,

J. Smith, R. Winbush, M. Hernandez

How Special Collections Contribute to Undergraduate Learning: Best

Practices in College Libraries,

J. Sahak, S. Allen

Change or Be Changed: Accountability Issues in Traditional, Flattened, and Team-based Organizations, V. Goodwin, S. Hay, R. Crumrin, C. Sercan, L. Bishoff

Taking the Lead: The Role of the Library and Information Provider in the Age of the World Wide Web, M. Carrig, A. Zygielbaum, D. Bosseau, B. Collins, J. Trolley 
DQ146-62

$\$ 8.00$

MQ146-63

$\$ 8.00$

MQ146-64

$\$ 8.00$
Organizational Transformation

through Incremental Change: One Library's Ongoing Success Story,

K. Croneis, S. Baker, J. Fox,

C. Antoniewicz, J. Kerckhove

Securing Full Opportunity in American Society: If Affirmative Action is Not Our Best Strategy, Then What? S. Creth, J. Koyama, W. Welburn, R. Scherrei, F. O'Brien

The Student-Centered Electronic Teaching Library: A New Model for Learning, I. Rockman, P. Adalian, Jr., 1. Hoffman, J. Swanson,

Purchase 12 Tape Vinyl Storage Album For $\$ 3.00$ or $\$ 5.00$ without purchase of cassette
M0146-65AB Interactive Session-"Choosing

$\$ 16.00$ Your Future", Introduction: W. Hisle;

(2 Tapes) Tribute to Paul Evan Peters,

Prepared by: P. Wand, D. Webster, J. Lippincott; The Learning Paradox: Creating New Security and Thriving Amid Uncertainty, J. Harris; Creating Our Futures, L. Bishoff

\section{DISCOUNTS}

THE COMPLETE SET MQ146 (63 Tapes) ONLY . . \$ \$399.00 SAVE OVER . . 20\% Includes FREE Vinyl Storage Albums

\section{Buy 6 Tapes Get The 7th FREE}

\section{FOR FASTER SERVICE}

Please have your credit card number and order ready and call

Monday - Friday 8AM-5PM Pacitic Standard Time

Call Local - 714 - 530 - 3454 TOLL-FREE: USAVAanada - 800 - 367 - 9286 International call - 714 - 530 - 3454 FAX your order - 714 - 537 - 3244

\section{ALL SALES FINAL}

International Orders: Add $10 \%$ surcharge of sub-total for additional shipping. All payments must be an International money order In U.S. Dollars, Traveler Checks in U.S. Dollars, or an International Credit Card (M/C, Visa or AE) PURCHASE ORDERS ACCEPTED FOR \$100 OR MORE (Signed purchase order form must be included) A $\$ 25.00$ fee will be charged on all retumed checks
* OF TAPES $X$ TOTAL PRICE:

AUDIO STORAGE ALBUMS $\$ 3.00 \times$

(Holds 12 Tapes)

CA residents add applicable sales tax:

DISCOUNTS -SUB-TOTAL

SHIPPING AND HANDUNG: USA, Canada, Mexico: (Include $\$ 1$ per tape, up to a maximum of \$10)

INTERNATIONAL SHIPPING - AIRMAIL: (Include $\$ 1$ per tape, up to a maximum of \$10; PLUS Additional $10 \%$ surcharge of 'SUb-Total)

TOTAL AMOUNT ENCLOSED:

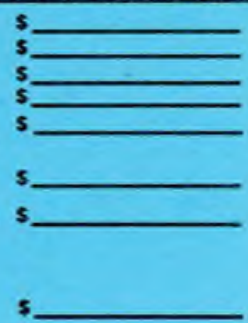

CHARGE TO: $\square$ M.C. $\square$ VISA $\square$ AVE $\square$ DISCOVER $\square$ My Check is Enclosed ACCT. \# Expires

Signature

Day Time Phone \#

Name

Address

City/State/Zip

Please Check: $\square$ cOMMERCIAL ADDRESS

RESIDENTIAL ADDRESS

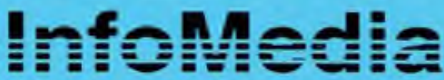

12800 Garde Grove Blvd. Suite F Garden Grove, CA 92843 
lar goals and requirements, teaching methods, faculty research interests, and student learning abilities and styles.

Professional and outreach service activities are the means by which librarians attempt to serve their clientele by influencing information policy development, the research into improved preservation techniques, information science research, and the development and application of information technology.

This often includes identifying and collaborating with strategic partners and allies such as national and local governments and industries and nonprofit organizations concerned with information policy and technology. Professional library organizations are also instrumental in setting standards for information organization, delivery, and preservation. In outreach service, librarians apply their expertise to situations outside of the academy, and educate the lay public on issues relating to access to information.

The importance of academic librarians' service activities to the library, institution, and greater community typically calls for such activities to be valued highly in performance reviews.

Service in academic librarianship includes but is not limited to:

- Institutional service-participation in committees, councils, task forces, the faculty governance body; participation in institutional activities such as colloquia and seminars; fundraising on behalf of the institution or library.

- Professional service-serving as an officer in professional organizations; participating in committees, councils, accrediting bodies, or task forces; editing a scholarly journal; refereeing competitive paper sessions or scholarly articles submitted for publication; serving as reviewer of new publications for professional journals; reviewing grant proposals.

- Outreach service-sharing professional expertise with parties outside the institution, such as serving as a consultant or writing for lay audiences on subjects related to librarianship, intellectual freedom, and censorship.

As other associations have found when attempting to apply the Rice/Boyer taxonomy of scholarship to their own disciplines, there can be some overlap among the various categories which results in occasional uncertainty over how a certain faculty activity ought to be classified. However, as the Association of American Geographers (AAG) wrote:
General definitions will remain arguable and imprecise, but each institution should have little difficulty formulating its own appropriate conceptualizations, assuming it has clearly articulated missions. Such imprecision and variations do not gainsay the validity of this or any other general schema, or the roles they attempt to encapsulate. .. . [The various categories]-whatever the fuzziness of their boundaries generally and locally-inform and enrich each other. They form a continuum of creative and peclagogical activities that differ less in content and mode than in the locations where they play out and in the clienteles they address. ${ }^{4}$

\section{Conclusions and recommendations}

Although it is all too common that we speak as if postsecondary educational institutions were identical in their aims and goals, the fact is that the missions of some colleges and universities emphasize research much more than do other institutions. Even within this dualistic picture there are varying degrees of value placed on the different performance categories. It is therefore to be expected that reward structures will differ according to institutional missions. It is natural that departments of chemistry or philosophy at research universities might focus on developing outstanding programs of scholarly inquiry while their counterparts at liberal arts or community colleges would concentrate much more on teaching and service. However, the basic functions and responsibilities of academic librarians for ensuring high-quality library services will vary much less among institutions with differing missions. In light of that, we recommend that institutions should develop reward structures for academic librarians that recognize and encourage their roles as articulated in the foregoing, whether the librarians have faculty status or not.

The reward structures and criteria for assessing performance should be clearly documented and shared with academic librarians. The extent to which different weights are given to each performance category should be related to the institutional mission and library goals. As an example, a land-grant university's emphasis on outreach might lead to its valuing service by the librarians to an even higher degree than service may be valued at other institutions. Similarly, some institutions will place a high value on the publication or presentation 
of academic librarian scholarship, while others will expect librarians to engage in scholarship but not necessarily write for publication.

Where librarians are expected to share their scholarship through books, refereed articles, presentations, etc., it is essential that the institutions take into account the fact that librarian "contact hours" are usually 35 to 40 hours per week, not the 12 to 24 that instructional faculty may have through classes and office hours. On one hand, it is critically important to both the quality of library services and to the efforts of librarians to publish their scholarship that sufficient time and resources be available to allow for scholarly writing without having a deleterious effect on library service. On the other hand, where librarians are not required to write for publication it is expected that they should show evidence of having applied continual critical professional judgment in staying abreast of and applying the latest trends and knowledge in their areas of expertise.

It should also be noted that different individuals make different kinds of contributions to the success of a program. Performance criteria and reward structures should enable librarians to contribute in the ways that best utilize their individual talents, which should in turn assure that the overall goals of the library are achieved.

Finally, as is noted in the Association of American Geographers' statement on behalf of their discipline, present reward structures usually focus almost exclusively on individualistic conceptions of faculty work. The AAG believes that collaborative efforts such as instructional teams may become more common in geography as their utility is demonstrated. This strikes

\section{Interested in shaping the future of ACRL?}

ACRL is looking for participants for its member services focus group at the ALA Annual Conference in San Francisco this month. Directed at collecting information that will help improve services and programs to members, the one-hour meeting will take place on Monday, June 30, 10:00-11:00 a.m. We invite you to participate by sending an e-mail message to ACRL at ACRL@ala.org by June 20 saying that you will participate in the focus group. a chord with academic librarians, not only because so much of their work is carried out through the collaborative work of professional service (e.g., setting standards for the discipline, influencing public policy) but also because so much of what librarians do is interdependent. As Janet Swan Hill described the situation:

In librarianship, some activities may be individually attributable, but most are not. For instance, a cataloger may prepare a bibliographic record for an item, but the individual work must be absorbed successfully into the catalog, and the highest quality work stands out least. Even activities that seem to be individually attributable may not be. For example, a reference librarian who is unable to find a useful information resource may owe that inability to a bibliographer who did not request it, an acquisitions librarian who could not identify it, a cataloger who did not analyze it fully, or a system vendor who failed to resolve a programming bug. ${ }^{5}$

Thus the cooperative nature of the field of academic librarianship is already such that we join the AAG in recommending that higher education institutions seek means of recognizing and rewarding collaborative accomplishments rather than continuing to focus solely on individualistic conceptions of faculty work.

\section{Notes}

1. Ernest L. Boyer, Scholarship Reconsidered: Priorities of the Professoriate (Princeton, N.J.: Carnegie Foundation for the Advancement of Teaching, 1990)

2. R. Eugene Rice, Making a Place for the New American Scholar, American Assoc. for Higher Education Working Paper No. 1 (1996).

3. ACRL/BIS Task Force on Model Statement of Objectives, "Model Statement of Objectives for Academic Bibliographic Instruction: Draft Revision," CERL News 48 (May 1987): 256-61.

4. Association of American Geographers, "Toward a Reconsideration of Faculty Roles and Rewards in Geography," in Robert M. Diamond and Bronwyn Adam, eds., The Disciplines Speak: Rewarding the Scbolarly, Professional, and Creative Work of Faculty (Washington, D.C.: American Association for Higher Education), 35-47.

5. Janet Swan Hill, "Wearing Our Own Clothes: Librarians As Faculty," Joumal of Academic Librarianship 20 (May 1994) 71-76. 


\section{The}

S

State

Information

industry leaders in providing of the Art subscription services, article delivery \& library automation software.

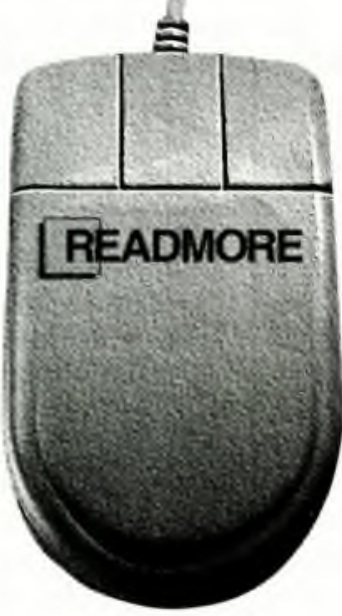

...working

smart

ROSS $^{\circledR}$ Online ordering, claiming and searching of journal and publisher databases.

Remo ${ }^{\mathbb{R}}$ Mouse driven serials management system.

Electronic Interfaces \& Customized Automated Management Products

ReadiCat Our comprehensive Internet catalog of serial titles searchable by a number of access points.

\section{Backserv/BackMed}

Internet lists solely devoted to the informal exchange of serial back issues among libraries.

\section{World Wide Web}

http://www.readmore.com

READMORE, INC.

22 Cortlandt Street

Phone: 1-800-221-3306

New York, NY 10007

Fax: 212-233-0746 